\title{
Online Appendix: Tipping and the Effects of Segregation
}

\author{
Anders Bohlmark \\ (Stockholm University) \\ Alexander Willén \\ (Norwegian School of Economics)
}




\section{APPENDIX FOR ONLINE PUBLICATION ONLY}

\section{Appendix A - The Structural Break Method}

This method is similar to that of identifying breaks in time series data, and consists of estimating the following regression

$D n_{s, m, t}=\alpha_{m}+d_{m} \mathbf{1}\left[i_{s, m, t-10}>i_{m, t-10}^{*}\right]+\varepsilon_{s, m, t}, \quad$ for $0 \leq i_{s, m, t-10} \leq I$

where $D n_{s, m, t}=\frac{N_{s, m, t}-N_{s, m, t-10}}{P_{s, m, t-10}}$ and represents the change in the native population in neighborhood $s$ in metropolitan area $m$ between $t-10$ and $t$, and $d_{m} \mathbf{1}\left[i_{s, m, t-10}>i_{m, t-10}^{*}\right]$ is an indicator variable that takes the value of one if the immigrant share in the neighborhood exceeds the tipping point of the metropolitan area.

To obtain estimates of the tipping points in the metropolitan areas, $i_{m, t-10}^{*}$, we restrict the tipping points to be in the interval $[0,50 \%]$ and choose the values that maximizes $R^{2}$ of the above equation, separately for each metropolitan area. According to Card et al. (2008), this method works well for identifying tipping points in large cities, but performs less well in small cities due to a tendency to identify tipping points that reflects clear outliers. Given the average size of the metropolitan areas in Sweden it is therefore inappropriate to rely on this strategy for the purpose of identifying the tipping points. 


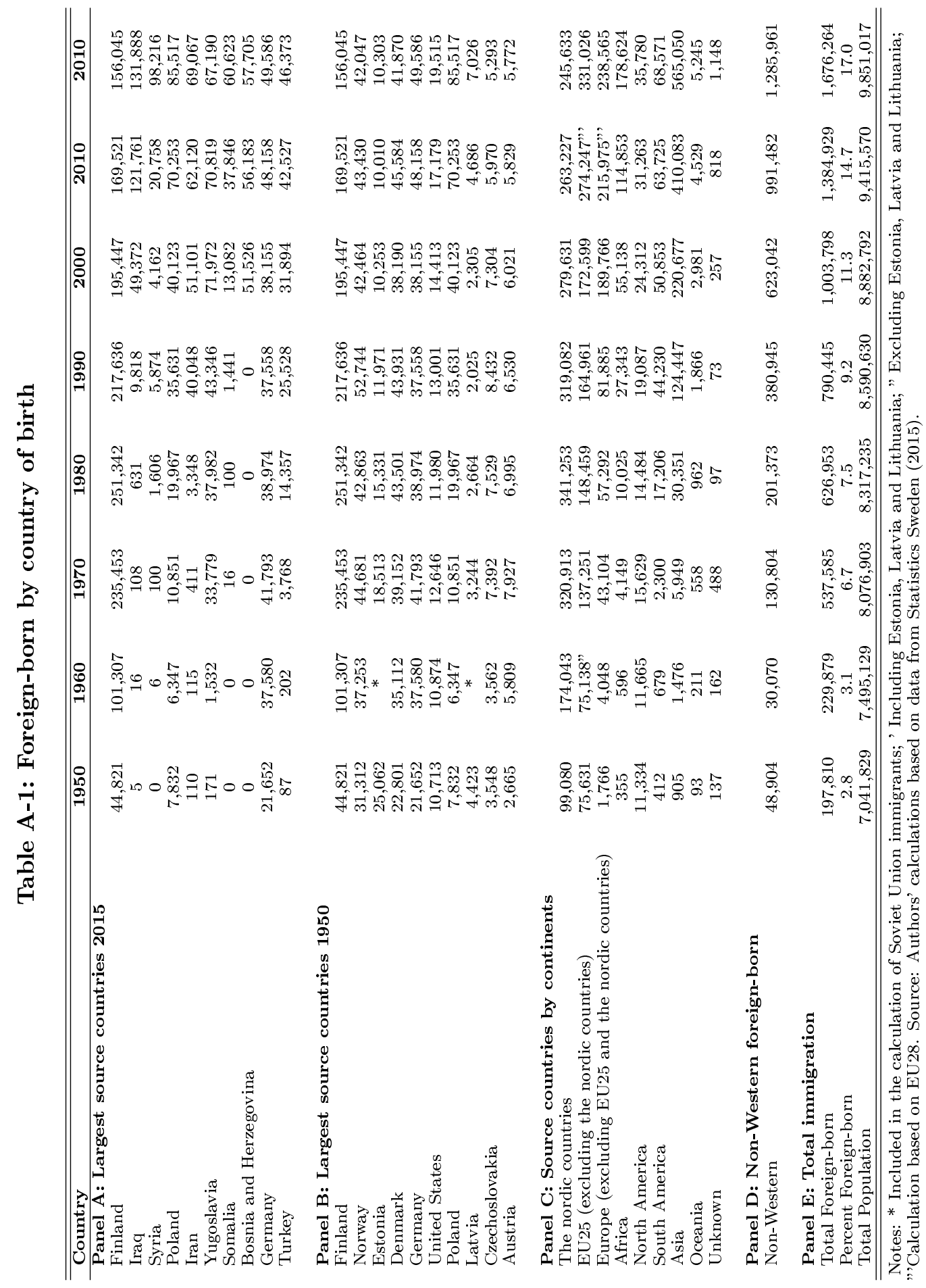


Table A-2: Neighborhood crossovers

\begin{tabular}{ccccccccccc}
\hline \hline Year of tipping & 1990 & 1991 & 1992 & 1993 & 1994 & 1995 & 1996 & 1997 & 1998 & 1999 \\
\hline Neighborhoods & 156 & 16 & 9 & 8 & 9 & 5 & 6 & 4 & 4 & 1 \\
\hline \hline
\end{tabular}

Notes: The tables shows the number of neighborhoods in which the share of non-Western immigrants increased from being below the candidate tipping point in 1990 to being above the treshold for each year between 1991 and 1999. The table further shows the number of neighborhoods that had immigrant shares above the identified tipping pooint in 1990 . The sample used is the $1 / 3$ sample not used for identifying the location of the tipping points. 
Table A-3: Donut-style regression discontinuity models for changes in native population around candidate tipping points

\begin{tabular}{lccccc}
\hline \hline \multicolumn{5}{c}{ Change in native population } \\
\hline & 0.10 & 0.3 & 0.5 & 1.00 & 2.00 \\
& $\begin{array}{c}\text { Donut Hole } \\
(\mathrm{i})\end{array}$ & $\begin{array}{c}\text { Donut Hole } \\
(\mathrm{ii})\end{array}$ & $\begin{array}{c}\text { Donut Hole } \\
(\text { iii })\end{array}$ & $\begin{array}{c}\text { Donut Hole } \\
(\text { iv })\end{array}$ & $\begin{array}{c}\text { Donut Hole } \\
(\mathrm{v})\end{array}$ \\
\hline Beyond TP & $-0.095^{* *}$ & $-0.093^{* *}$ & $-0.096^{* *}$ & $-0.104^{* *}$ & $-0.109^{* *}$ \\
& $(0.039)$ & $(0.042)$ & $(0.042)$ & $(0.046)$ & $(0.049)$ \\
Observations & 517 & 514 & 511 & 501 & 488 \\
\hline \hline
\end{tabular}

Notes: The unit of observation is a neighborhood as identified by the SAMS code.

Results are obtained from estimating equation (2). Across the columns, neighborhoods with base year immigrant shares $+/-0.05$ (i), 0.15 (ii), 0.25 (iii), 0.50 (iv) and 1.00 (v) of the identified tipping point are excluded from the estimation. Years of treatment has been instrumented by whether the neighborhood was above or below the tipping point in the base year. All specifications include a quartic polynomial in the difference between the neighborhood's minority share and the estimated tipping point. Standard errors are clustered on one percent bins of the running variable. The sample used for estimation is the $1 / 3$ sample not used for identifying the tipping points. Demographic controls are years of schooling, income and gender, all measured in the base year. The regressions are weighted by the size of the neighborhoods. All specifications include metropolitan area fixed effects. ${ }^{* *}$ indicates significance at the $1 \%$ level, $* *$ indicates significance at the $5 \%$ level and $*$ indicates significance at the $10 \%$ level. 
Table A-4: Regression discontinuity models for population changes around candidate tipping points, Western immigrants

\begin{tabular}{lccc}
\hline \hline & Native Growth & Western Immigrant Growth & Non-Western Immigrant Growth \\
\hline \multirow{2}{*}{ Beyond TP } & -0.027 & -0.002 & -0.003 \\
& $(0.060)$ & $(0.007)$ & $(0.027)$ \\
Observations & 520 & 520 & 520 \\
\hline \hline
\end{tabular}

Notes: The unit of observation is a neighborhood as identified by the SAMS code. The results are obtained from estimating new tipping points based on fraction Western immigrants using equation (1), and then using these new candidate thresholds to estimate equation (2). All specifications include a quartic polynomial in the difference between the neighborhood's minority share and the estimated tipping point. Standard errors are clustered on one percent bins of the running variable. The sample used for estimation is the $1 / 3$ sample not used for identifying the location of the tipping points. Demographic controls are years of schooling, income and gender, all measured in the base year. The regressions are weighted by the size of the neighborhoods. All specifications include metropolitan area fixed effects. $* * *$ indicates significance at the $1 \%$ level, $* *$ indicates significance at the $5 \%$ level and * indicates significance at the $10 \%$ level. 
Table A-5: Sensitivity analysis on the change in native population growth around the candidate tipping point

\begin{tabular}{|c|c|c|c|c|c|c|c|c|c|}
\hline & (i) & (ii) & (iii) & (iv) & $(\mathrm{v})$ & (vi) & (vii) & (viii) & (ix) \\
\hline Beyond TP & $\begin{array}{l}-0.088^{* *} \\
(0.029)\end{array}$ & $\begin{array}{l}-0.092^{* *} \\
(0.040)\end{array}$ & $\begin{array}{l}-0.109^{* * *} \\
(0.039)\end{array}$ & $\begin{array}{l}-0.091^{* *} \\
(0.041)\end{array}$ & $\begin{array}{l}-0.091^{* *} \\
(0.039)\end{array}$ & $\begin{array}{l}-0.089^{*} \\
(0.048)\end{array}$ & $\begin{array}{l}-0.091^{* *} \\
(0.042)\end{array}$ & $\begin{array}{l}-0.091^{* *} \\
(0.039)\end{array}$ & $\begin{array}{l}-0.082^{* * *} \\
(0.036)\end{array}$ \\
\hline Polynomial & Linear & Quadratic & Cubic & Quartic & Quartic & Quintic & Quartic & Quartic & Quartic \\
\hline Baseline Controls & $\mathrm{x}$ & $\mathrm{x}$ & $\mathrm{x}$ & & $\mathrm{x}$ & $\mathrm{x}$ & $\mathrm{x}$ & $\mathrm{x}$ & $\mathrm{x}$ \\
\hline Fully Interacted & & & & & & & $\mathrm{x}$ & & \\
\hline Additional Controls & & & & & & & & $\mathrm{x}$ & \\
\hline Control for Population Density & & & & & & & & & $\mathrm{x}$ \\
\hline Observations & 520 & 520 & 520 & 520 & 520 & 520 & 520 & 520 & 520 \\
\hline R-squared & 0.287 & 0.287 & 0.302 & 0.233 & 0.305 & 0.305 & 0.305 & 0.334 & 0.313 \\
\hline
\end{tabular}

Notes: The unit of observation is a neighborhood as identified by the SAMS code. The results are obtained from estimating equation (2). Dependent variable is change in native population between 1990 and 2000. Standard errors are clustered on one percent bins of the running variable. The sample used for estimation is the $1 / 3$ sample not used for identifying the location of the tipping points. Baseline controls are years of schooling, income and gender, all measured in the base year. Additional controls are years since migration, number of children in household and social welfare recipient status. The regressions are weighted by the size of the neighborhoods. All specifications include metropolitan area fixed effects. ${ }^{* * *}$ indicates significance at the $1 \%$ level, $* *$ indicates significance at the $5 \%$ level and $*$ indicates significance at the $10 \%$ level. 
Table A-6: Regression discontinuity models for changes in residential population composition around candidate tipping points, local linear regression

\begin{tabular}{lccc}
\hline \hline & Native Growth & Immigrant Growth & Population Growth \\
\hline Beyond TP & $-0.112^{* *}$ & 0.005 & $-0.107^{*}$ \\
& $(0.050)$ & $(0.021)$ & $(0.057)$ \\
R-squared & 0.190 & 0.301 & 0.080 \\
Observations & 433 & 433 & 433 \\
\hline \hline
\end{tabular}

Notes: The unit of observation is a neighborhood as identified by the SAMS code. The bandwidth has been chosen using the cross-validation method proposed by Ludwig and Miller (2005). $h=11.58483$. The sample used for estimation is the $1 / 3$ sample not used for identifying the location of the tipping points. Demographic controls are years of schooling, income and gender, all measured in the base year. The regressions are weighted by the size of the neighborhoods. All specifications include metropolitan area fixed effects. $* * *$ indicates significance at the $1 \%$ level, $* *$ indicates significance at the $5 \%$ level and $*$ indicates significance at the $10 \%$ level. 


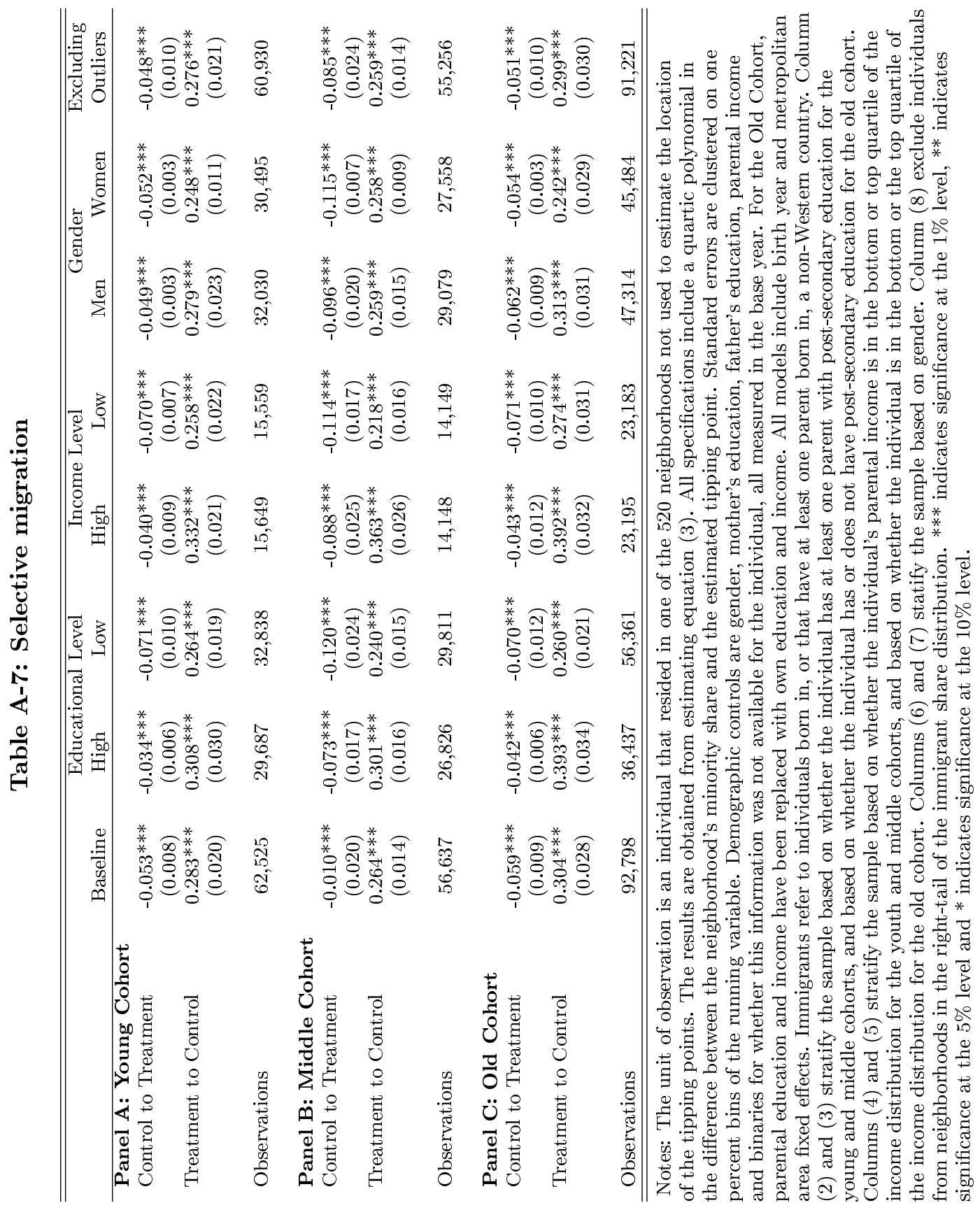


Table A-8: The reduced-form effect of neighborhood composition on cognitive and non-cognitive military test scores

\begin{tabular}{lcc}
\hline \hline & Cognative & Non-cognative \\
\hline $\begin{array}{l}\text { Panel A: Immigrants } \\
\text { i. 1973-1983 }\end{array}$ & & \\
Beyond TP & 0.008 & -0.070 \\
& $(0.198)$ & $(0.196)$ \\
i. 1973-1980 & & \\
Beyond TP & -0.070 & -0.169 \\
& $(0.242)$ & $(0.212)$ \\
Panel B: Natives & & \\
$i$. 1973-1983 & & \\
Beyond TP & -0.048 & 0.128 \\
& $(0.066)$ & $(0.083)$ \\
$i$. 1973-1980 & & \\
Beyond TP & -0.017 & $0.183^{*}$ \\
& $(0.061)$ & $(0.097)$ \\
\hline \hline
\end{tabular}

Notes: The unit of observation is an individual that was started school 1973-1983 (Row 1) or 1973-1980 (Row 2) and resided in one of the 520 neighborhoods included in our analysis in the base year. The results are obtained from estimating equation (3). All specifications include a quartic polynomial in the difference between the neighborhood's minority share and the estimated tipping point. Standard errors are clustered on one percent bins of the running variable. Demographic controls are gender, mother's education, father's education, parental income and indicators for whether this information was not available for the individual. All models include birth year and metropolitan area fixed effects. Immigrants refer to individuals born in, or that have at least one parent born in, a non-Western country. ${ }^{* * *}$ indicates significance at the $1 \%$ level, ** indicates significance at the $5 \%$ level and * indicates significance at the $10 \%$ level. 
Table A-9: Fraction of individuals that maintain treatment status over time

\begin{tabular}{ccccccc}
\hline \hline & \multicolumn{2}{c}{ All } & \multicolumn{2}{c}{ Natives } & \multicolumn{2}{c}{ Immigrants } \\
Year & Control & Treatment & Control & Treatment & Control & Treatment \\
\hline 1991 & 0.85 & 0.82 & 0.85 & 0.79 & 0.85 & 0.87 \\
1992 & 0.79 & 0.73 & 0.79 & 0.70 & 0.77 & 0.78 \\
1993 & 0.74 & 0.64 & 0.74 & 0.62 & 0.70 & 0.70 \\
1994 & 0.68 & 0.58 & 0.68 & 0.55 & 0.64 & 0.64 \\
1995 & 0.64 & 0.53 & 0.64 & 0.50 & 0.61 & 0.59 \\
1996 & 0.59 & 0.49 & 0.59 & 0.46 & 0.56 & 0.54 \\
1997 & 0.56 & 0.45 & 0.56 & 0.42 & 0.54 & 0.51 \\
1998 & 0.52 & 0.41 & 0.52 & 0.39 & 0.50 & 0.47 \\
1999 & 0.49 & 0.39 & 0.49 & 0.36 & 0.48 & 0.45 \\
2000 & 0.48 & 0.37 & 0.47 & 0.35 & 0.47 & 0.43 \\
\hline \hline
\end{tabular}

Notes: The unit of observation is an individual that resided in one of the 520 neighborhoods included in our analysis in the base year. The Treatment columns depict the fraction of individuals that resided in a neighborhood with an immigrant share above the candidate threshold in the base year and remained in a neighborhood with an immigrant share above the threshold in year t. The Control columns depict the fraction of individuals that resided in a neighborhood with an immigrant share below the candidate threshold in the base year and remained in a neighborhood with an immigrant share below the threshold in year $t$. 
Table A-10: Neighborhood population density

\begin{tabular}{lcccc}
\hline \hline & All & Stockholm & Gothenburg & Malmo \\
\hline Mean & 4074.34 & 2437.36 & 5595.21 & 5326.58 \\
S.D. & 4535.89 & 2992.11 & 5390.15 & 4414.88 \\
\hline \hline
\end{tabular}

Notes: Authors' own calculations based on information on land size from Jan Amcoff and data from IFAU. See Amcoff (2012) for detailed information on how the density measure was constructed. 
Table A-11: Tipping behavior of neighboring neighborhoods

\begin{tabular}{lccccc}
\hline \hline & Mean & $\begin{array}{c}\text { Standard } \\
\text { Deviation }\end{array}$ & $\begin{array}{c}\text { No Tipped } \\
\text { Neighbors }\end{array}$ & $\begin{array}{c}\text { All Neighbors } \\
\text { Tipped }\end{array}$ & $\begin{array}{c}\text { Number of Tipped } \\
\text { Neighborhoods }\end{array}$ \\
\hline All & 0.62 & 0.35 & 0.12 & 0.25 & 459 \\
Stockholm & 0.43 & 0.29 & 0.17 & 0.08 & 166 \\
Gothenburg & 0.75 & 0.34 & 0.09 & 0.53 & 208 \\
Malmo & 0.65 & 0.31 & 0.09 & 0.24 & 85 \\
\hline \hline
\end{tabular}

Notes: Authors' own calculations using Statistic Sweden's SAMS Atlas. In a first step, neighborhoods with immigrant shares above the threshold in the base year are identified. In a second step, the SAMS Atlas is used to obtain the names of the neighborhoods surrounding the tipped neighborhoods. Finally,data from IFAU is used to identify the fraction of these neighborhoods that have tipped. 


\section{Table A-12: The reduced form effect of neighborhood composition on short-term labor market outcomes}

\begin{tabular}{lccc}
\hline \hline & $\begin{array}{c}\text { Self-Employment } \\
\text { Income }\end{array}$ & $\begin{array}{c}\text { Employment } \\
\text { Income }\end{array}$ & $\begin{array}{c}\text { Government-Funded } \\
\text { Benefits }\end{array}$ \\
\hline $\begin{array}{l}\text { Panel A: Immigrants } \\
\text { i. Intensive Margin }\end{array}$ & -0.220 & 0.026 & 0.015 \\
Beyond TP & $(0.171)$ & $(0.045)$ & $(0.068)$ \\
& 1803 & 16007 & 6704 \\
Observations & & & \\
ii. Extensive Margin & 0.009 & 0.018 & -0.007 \\
Beyond TP & $(0.006)$ & $(0.020)$ & $(0.014)$ \\
& 23253 & 23253 & 23253 \\
Observations & & & \\
Panel B: Natives & -0.136 & 0.007 & -0.020 \\
i. Intensive Margin & $(0.127)$ & $(0.023)$ & $(0.054)$ \\
Beyond TP & 6315 & 81268 & 25528 \\
& & & \\
Observations & 0.006 & -0.003 & $-0.017^{* *}$ \\
$\begin{array}{l}\text { i. Extensive Margin } \\
\text { Beyond TP }\end{array}$ & $(0.009)$ & $(0.011)$ & $(0.008)$ \\
& & & 93953 \\
\hline Observations & 93953 & 93953 & \\
\hline \hline
\end{tabular}

Notes: The unit of observation is an individual born between 1948 and 1958 that resided in one of the 520 neighborhoods included in our analysis that were not used to estimate the location of the tipping point . The results are obtained from estimating equation (3). All specifications include a quartic polynomial in the difference between the neighborhood's minority share and the estimated tipping point. Standard errors are clustered on one percent bins of the running variable. Demographic controls are gender, years of schooling, income and indicators for whether this information was not available for the individual. All models include birth year and metropolitan area fixed effects. All dependent variables are measured in 2000. All controls are measured in 1990. Immigrants refer to individuals born in, or that have at least one parent born in, a non-Western country. $* * *$ indicates significance at the $1 \%$ level, $* *$ indicates significance at the $5 \%$ level and * indicates significance at the $10 \%$ level. 
Table A-13: Descriptive statistics of neighborhoods included/excluded from analysis

\begin{tabular}{lcc}
\hline \hline & Included & Excluded \\
\hline Fraction Natives & $0.81(0.14)$ & $0.82(0.21)$ \\
Fraction Females & $0.49(0.03)$ & $0.43(0.17)$ \\
Age & $39.33(2.97)$ & $41.02(6.19)$ \\
Years Since Migration & $17.26(3.92)$ & $17.90(8.12)$ \\
Fraction With University Education & $0.10(0.08)$ & $0.08(0.12)$ \\
Employment Income (000s SEK) & $165.52(46.81)$ & $138.78(70.34)$ \\
Fraction on Social Welfare & $0.07(0.09)$ & $0.07(0.16)$ \\
Native Growth Rate & $0.09(0.30)$ & $2.48(17.12)$ \\
Immigrant Growth Rate & $0.07(0.12)$ & $0.91(7.02)$ \\
Total Growth Rate & $0.15(0.33)$ & $3.39(23.80)$ \\
\hline \hline
\end{tabular}

Notes: Authors' own calculations using population-wide registry data from IFAU. Values represent unweighted means, and standard deviations are provided in brackets. Salary refers to income from primary occupation, and includes zeros. 
Table A-14: The effect of tipping on neighborhood environment

\begin{tabular}{lcc}
\hline \hline & $\begin{array}{c}\text { Economic Activity } \\
\text { Index }\end{array}$ & $\begin{array}{c}\text { Sociodemographic } \\
\text { Index }\end{array}$ \\
\hline Neighborhood Analysis & & $-0.339^{* * *}$ \\
All & -0.073 & $(0.101)$ \\
& $(0.056)$ & $-0.260^{* * *}$ \\
Individual-level Analysis & & $(0.088)$ \\
All & -0.101 & $-0.239^{* * *}$ \\
Natives & $(0.117)$ & $(0.082)$ \\
& -0.074 & $-0.273^{* *}$ \\
Immigrants & $(0.121)$ & $(0.112)$ \\
& -0.107 & $-0.303^{* * *}$ \\
Stayers & $(0.119)$ & $(0.109)$ \\
& -0.209 & $-0.157^{* *}$ \\
Leavers & $(0.150)$ & $\left(0.083^{*}\right)$ \\
& 0.031 & $(0.086)$ \\
\hline \hline
\end{tabular}

Notes: The unit of observation is an individual that resided in one of the 520 neighborhoods not used to estimate the location of the tipping points. The neighborhood analysis results are obtained from estimating equation (2), while the individual level analysis results are obtained from estimating equation (3). All specifications include a quartic polynomial in the difference between the neighborhood's minority share and the estimated tipping point. Standard errors are clustered on one percent bins of the running variable. Demographic controls are gender, mother's education, father's education, parental income and binaries for whether this information was not available for the individual, all measured in the base year. For the Old Cohort, parental education and income have been replaced with own education and income. All models include birth year and metropolitan area fixed effects. Immigrants refer to individuals born in, or that have at least one parent born in, a non-Western country. The Economic Activity Index is based on three labor market variables (average employment income, average education, and fraction employed) while the Sociodemographic Index is based on four sociodemographic variables (gender balance, age profile, fraction immigrants and fraction on social security benefits). For each of these indices, we use unity-based normalization to bring the values of each of the individual variables into the range $[0,1]$, take their sum, and then standardize the index to have a mean of zero and a standard deviation of one. ${ }^{* *}$ indicates significance at the $1 \%$ level, $* *$ indicates significance at the $5 \%$ level and * indicates significance at the $10 \%$ level. 
Table A-15: The reduced form effect of neighborhood composition on immigrants, sensitivity table

\begin{tabular}{|c|c|c|c|c|c|c|}
\hline & $\begin{array}{l}\text { 9th grade } \\
\text { GPA }\end{array}$ & $\begin{array}{l}\text { 9th grade } \\
\text { Swedish }\end{array}$ & $\begin{array}{l}\text { High School } \\
\text { GDP }\end{array}$ & $\begin{array}{l}\text { Years of } \\
\text { schooling }\end{array}$ & $\begin{array}{l}\text { Empl. } \\
\text { Sample }\end{array}$ & $\begin{array}{l}\text { Empl. } \\
\text { Income }\end{array}$ \\
\hline $\begin{array}{l}\text { Panel A: Young Cohort } \\
\text { Population Density }\end{array}$ & $\begin{array}{c}0.880 \\
(1.677)\end{array}$ & $\begin{array}{c}1.410 \\
(1.959)\end{array}$ & $\begin{array}{c}0.319 \\
(1.574)\end{array}$ & $\begin{array}{c}0.021 \\
(0.097)\end{array}$ & $\begin{array}{c}0.013 \\
(0.019)\end{array}$ & $\begin{array}{c}0.231 \\
(0.230)\end{array}$ \\
\hline $\begin{array}{l}\text { Excl. Neighborhoods with } \\
100 \% \text { Tipped Neighbors }\end{array}$ & $\begin{array}{c}0.749 \\
(1.438)\end{array}$ & $\begin{array}{c}1.148 \\
(1.829)\end{array}$ & $\begin{array}{c}0.251 \\
(1.527)\end{array}$ & $\begin{array}{c}0.034 \\
(0.094)\end{array}$ & $\begin{array}{c}0.017 \\
(0.019)\end{array}$ & $\begin{array}{c}0.275 \\
(0.232)\end{array}$ \\
\hline Excluding Outliers & $\begin{array}{l}-2.194 \\
(1.612)\end{array}$ & $\begin{array}{c}1.111 \\
(1.823)\end{array}$ & $\begin{array}{c}0.056 \\
(1.661)\end{array}$ & $\begin{array}{l}-0.015 \\
(0.098)\end{array}$ & $\begin{array}{c}0.002 \\
(0.023)\end{array}$ & $\begin{array}{c}0.059 \\
(0.285)\end{array}$ \\
\hline $\begin{array}{l}\text { Panel B: Middle Cohort } \\
\text { Population Density }\end{array}$ & $\begin{array}{c}-0.353 \\
(1.220)\end{array}$ & $\begin{array}{l}-0.458 \\
(2.039)\end{array}$ & $\begin{array}{l}-0.396 \\
(1.950)\end{array}$ & $\begin{array}{c}0.153 \\
(0.149)\end{array}$ & $\begin{array}{c}0.003 \\
(0.020)\end{array}$ & $\begin{array}{c}0.080 \\
(0.251)\end{array}$ \\
\hline $\begin{array}{l}\text { Excl. Neighborhoods with } \\
100 \% \text { Tipped Neighbors }\end{array}$ & $\begin{array}{l}-0.181 \\
(1.108)\end{array}$ & $\begin{array}{l}-0.530 \\
(2.077)\end{array}$ & $\begin{array}{l}-0.553 \\
(1.818)\end{array}$ & $\begin{array}{c}0.154 \\
(0.162)\end{array}$ & $\begin{array}{c}0.005 \\
(0.019)\end{array}$ & $\begin{array}{c}0.105 \\
(0.237)\end{array}$ \\
\hline Excluding Outliers & $\begin{array}{l}-1.247 \\
(1.300)\end{array}$ & $\begin{array}{c}0.041 \\
(2.109)\end{array}$ & $\begin{array}{l}-0.288 \\
(2.117)\end{array}$ & $\begin{array}{c}0.199 \\
(0.161)\end{array}$ & $\begin{array}{c}0.000 \\
(0.019)\end{array}$ & $\begin{array}{c}0.045 \\
(0.241)\end{array}$ \\
\hline $\begin{array}{l}\text { Panel C: Old Cohort } \\
\text { Population Density }\end{array}$ & & & & & $\begin{array}{c}0.011 \\
(0.026)\end{array}$ & $\begin{array}{c}0.111 \\
(0.331)\end{array}$ \\
\hline $\begin{array}{l}\text { Excl. Neighborhoods with } \\
100 \% \text { Tipped Neighbors }\end{array}$ & & & & & $\begin{array}{c}0.020 \\
(0.028)\end{array}$ & $\begin{array}{r}0.232 \\
(0.353)\end{array}$ \\
\hline Excluding Outliers & & & & & $\begin{array}{c}0.009 \\
(0.029) \\
\end{array}$ & $\begin{array}{c}0.125 \\
(0.376) \\
\end{array}$ \\
\hline
\end{tabular}

Notes: The unit of observation is an individual that resided in one of the 520 neighborhoods included in our analysis in the base year. The results are obtained from estimating equation (3). All specifications include a quartic polynomial in the difference between the neighborhood's minority share and the estimated tipping point. Standard errors are clustered on one percent bins of the running variable. Demographic controls are gender, mother's education, father's education, parental income and binaries for whether this information was not available for the individual, all measured in the base year. For the Old Cohort, parental education and income have been replaced with own education and income. All models include birth year and metropolitan area fixed effects. Immigrants refer to individuals born in, or that have at least one parent born in, a non-Western country. ${ }^{* * *}$ indicates significance at the $1 \%$ level, ${ }^{* *}$ indicates significance at the $5 \%$ level and * indicates significance at the $10 \%$ level. 
Table A-16: The reduced form effect of neighborhood composition on natives, sensitivity table

\begin{tabular}{|c|c|c|c|c|c|c|}
\hline & $\begin{array}{l}\text { 9th grade } \\
\text { GPA }\end{array}$ & $\begin{array}{l}\text { 9th grade } \\
\text { Swedish }\end{array}$ & $\begin{array}{l}\text { High school } \\
\text { GDP }\end{array}$ & $\begin{array}{c}\text { Years of } \\
\text { schooling }\end{array}$ & $\begin{array}{c}\text { Empl. } \\
\text { Sample }\end{array}$ & $\begin{array}{l}\text { Empl. } \\
\text { Income }\end{array}$ \\
\hline $\begin{array}{l}\text { Panel A: Young Cohort } \\
\text { Population Density }\end{array}$ & $\begin{array}{c}-2.087 * * \\
(0.938)\end{array}$ & $\begin{array}{c}-1.530^{* *} \\
(0.748)\end{array}$ & $\begin{array}{c}-1.233^{* *} \\
(0.536)\end{array}$ & $\begin{array}{l}-0.078 \\
(0.050)\end{array}$ & $\begin{array}{l}-0.005 \\
(0.008)\end{array}$ & $\begin{array}{l}-0.081 \\
(0.100)\end{array}$ \\
\hline $\begin{array}{l}\text { Excl. Neighborhoods with } \\
100 \% \text { Tipped Neighbors }\end{array}$ & $\begin{array}{c}-2.086^{*} \\
(1.134)\end{array}$ & $\begin{array}{l}-1.696^{*} \\
(0.942)\end{array}$ & $\begin{array}{r}-1.127^{*} \\
(0.586)\end{array}$ & $\begin{array}{l}-0.063 \\
(0.054)\end{array}$ & $\begin{array}{c}0.001 \\
(0.007)\end{array}$ & $\begin{array}{c}0.013 \\
(0.096)\end{array}$ \\
\hline Excluding Outliers & $\begin{array}{l}-1.905 \\
(1.145)\end{array}$ & $\begin{array}{c}-1.694^{*} \\
(0.992)\end{array}$ & $\begin{array}{c}-1.181^{*} \\
(0.692)\end{array}$ & $\begin{array}{c}0.037 \\
(0.058)\end{array}$ & $\begin{array}{c}0.001 \\
(0.008)\end{array}$ & $\begin{array}{c}-0.004 \\
(0.105)\end{array}$ \\
\hline $\begin{array}{l}\text { Panel B: Middle Cohort } \\
\text { Population Density }\end{array}$ & $\begin{array}{r}-1.402^{*} \\
(0.724)\end{array}$ & $\begin{array}{c}-1.912^{* *} \\
(0.828)\end{array}$ & $\begin{array}{l}-0.034 \\
(0.756)\end{array}$ & $\begin{array}{l}-0.039 \\
(0.056)\end{array}$ & $\begin{array}{c}0.001 \\
(0.007)\end{array}$ & $\begin{array}{c}-0.005 \\
(0.088)\end{array}$ \\
\hline $\begin{array}{l}\text { Excl. Neighborhoods with } \\
100 \% \text { Tipped Neighbors }\end{array}$ & $\begin{array}{l}-1.209 \\
(0.732)\end{array}$ & $\begin{array}{c}-2.001^{* *} \\
(0.867)\end{array}$ & $\begin{array}{l}-0.046 \\
(0.771)\end{array}$ & $\begin{array}{l}-0.020 \\
(0.059)\end{array}$ & $\begin{array}{c}0.002 \\
(0.007)\end{array}$ & $\begin{array}{c}0.015 \\
(0.092)\end{array}$ \\
\hline Excluding Outliers & $\begin{array}{l}-0.947 \\
(0.681)\end{array}$ & $\begin{array}{r}-1.677^{*} \\
(0.901)\end{array}$ & $\begin{array}{c}0.390 \\
(0.893)\end{array}$ & $\begin{array}{c}0.009 \\
(0.060)\end{array}$ & $\begin{array}{l}-0.001 \\
(0.007)\end{array}$ & $\begin{array}{c}0.008 \\
(0.101)\end{array}$ \\
\hline $\begin{array}{l}\text { Panel C: Old Cohort } \\
\text { Population Density }\end{array}$ & & & & & $\begin{array}{l}-0.010 \\
(0.012)\end{array}$ & $\begin{array}{l}-0.151 \\
(0.163)\end{array}$ \\
\hline $\begin{array}{l}\text { Excl. Neighborhoods with } \\
100 \% \text { Tipped Neighbors }\end{array}$ & & & & & $\begin{array}{l}-0.002 \\
(0.012)\end{array}$ & $\begin{array}{l}-0.044 \\
(0.168)\end{array}$ \\
\hline Excluding Outliers & & & & & $\begin{array}{c}-0.010 \\
(0.012)\end{array}$ & $\begin{array}{c}-0.120 \\
(0.168)\end{array}$ \\
\hline
\end{tabular}

Notes: The unit of observation is an individual that resided in one of the 520 neighborhoods not used for identifying the location of the tipping points. The results are obtained from estimating equation (3). All specifications include a quartic polynomial in the difference between the neighborhood's minority share and the estimated tipping point. Standard errors are clustered on one percent bins of the running variable. Demographic controls are gender, mother's education, father's education, parental income and binaries for whether this information was not available for the individual, all measured in the base year. For the Old Cohort, parental education and income have been replaced with own education and income. All models include birth year and metropolitan area fixed effects. All models include birth year and municipality fixed effects. Natives refer to individuals not born in, and that do not have a parent born in, a non-Western country. $* * *$ indicates significance at the $1 \%$ level, $* *$ indicates significance at the $5 \%$ level and $*$ indicates significance at the $10 \%$ level. 


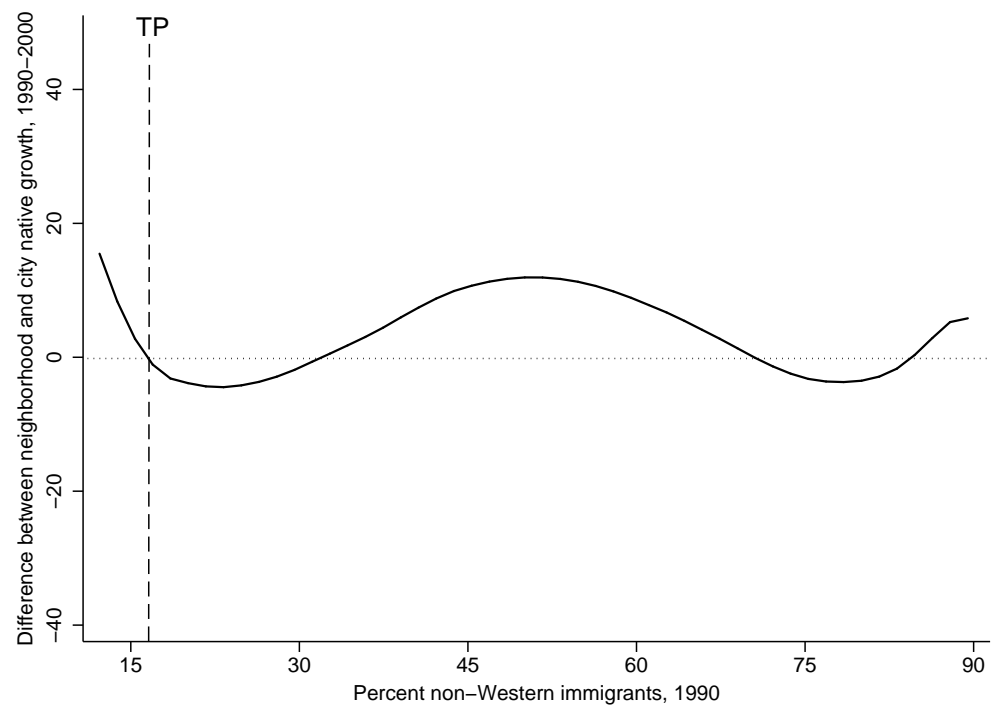

Figure A-1: Illustration of the search method for identifying the tipping point

Notes: The figure demonstrates how the location of the tipping point is derived from equation (1) for a hypothetical city. The solid line depicts the growth function of neighborhood native population modelled as a fourth-order polynominal. The horizontal line shows where the dependent variable of equation (1) is equal to zero. The proposed tipping point is located at the intersection of this line and the growth function, denoted by the dashed vertical line. As illustrated in the Figure, and discussed in the text, there can be more than one root, and in such cases we follow Card et al. (2008) and pick the root associated with the most negative slope. 


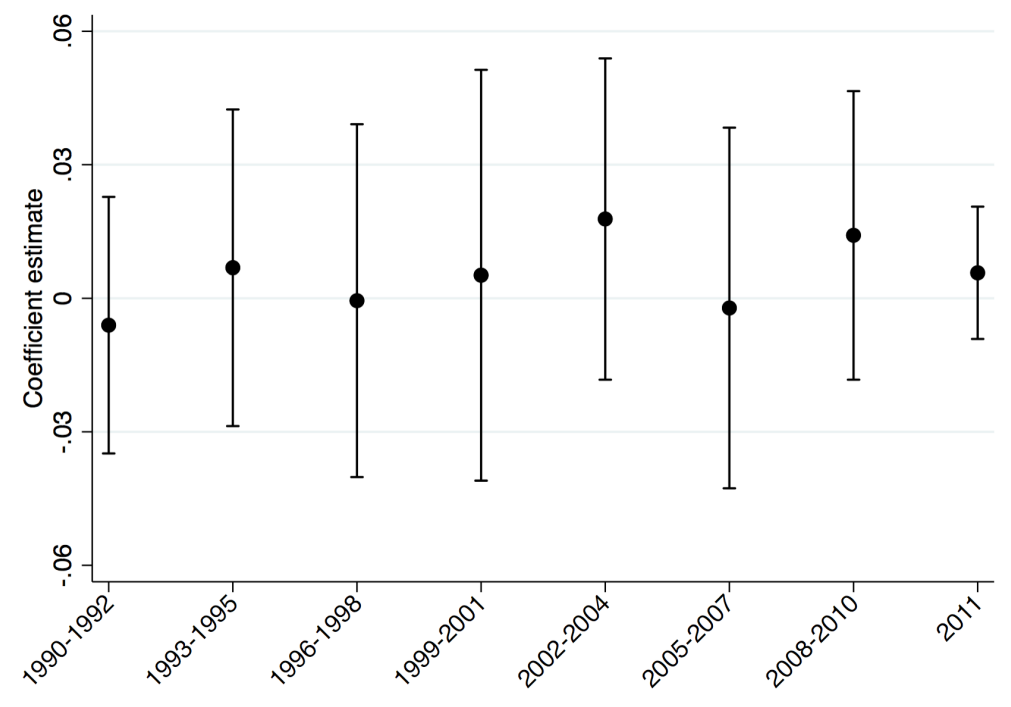

(a) Immigrants

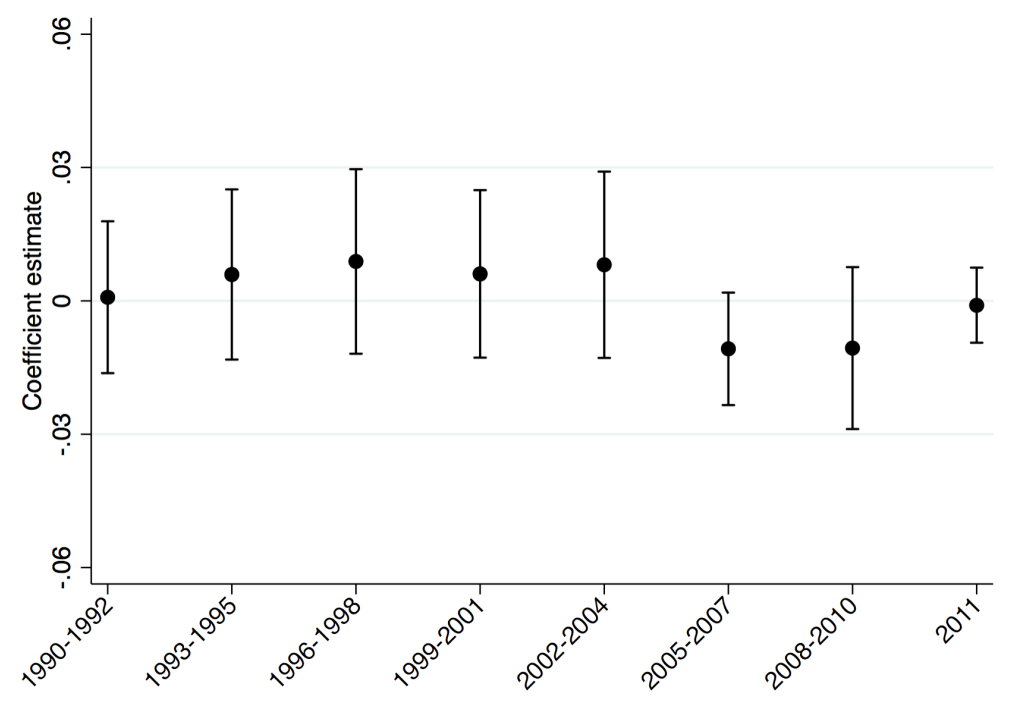

(b) Natives

Figure A-2: Time heterogeneity in treatment effects

Notes: The unit of observation is an individual born between 1948 and 1958 (Old Cohort) that resided in one of the 520 neighborhoods included in our analysis in the base year not used to identify the location of the tipping points. The figure depicts the point estimates obtained from estimating equation (4) seperateley on three year averages of employment income, stratified by nativity status. All specifications include a quartic polynomial in the difference between the neighborhood's minority share and the estimated tipping point. Standard errors are clustered on one percent bins of the running variable. Demographic controls are gender, educational attainment, income and binaries for whether this information was not available for the individual, all measured in the base year. All models include birth year and municipality fixed effects. Natives refer to individuals not born in, and do not have a parent born in, a non-Western country. The bars depict the $95 \%$ confidence intervals associated with each point estimate. 

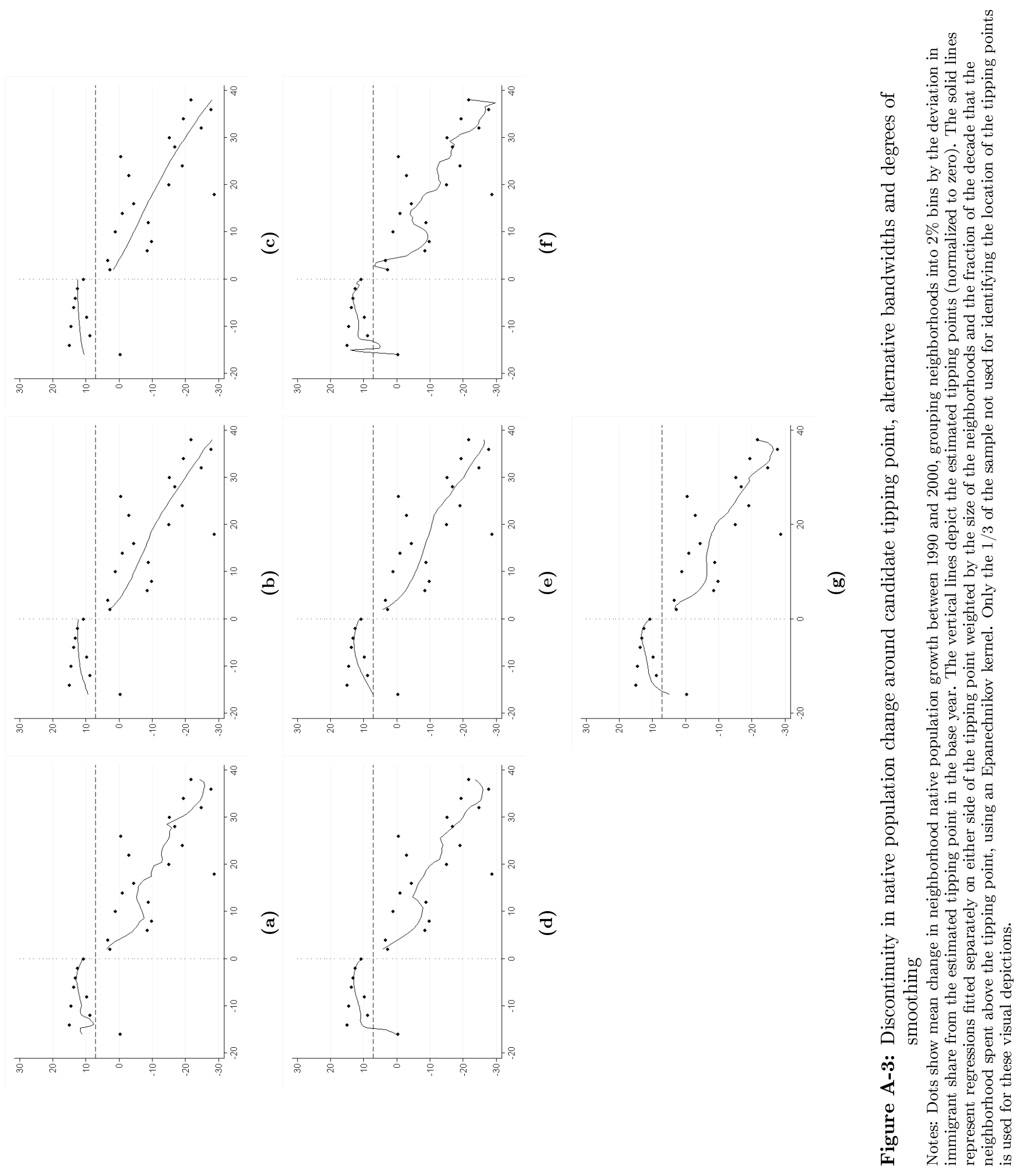